\title{
Remote cays and the pre-Columbian colonisation of The Bahamas
}

\author{
William F. Keegan ${ }^{1, *} \&$ Michael P. Pateman ${ }^{2}$
}

Recent research investigating the origins of Bahama archipelago habitation conducted archaeological surveys on the remote Bahamian Guinchos Cay and Cay Lobos. A complete lack of prehistoric evidence, however, suggests that they played no significant role in the colonisation of The Bahamas.

\section{Introduction}

A key unresolved question concerning the colonisation of the Caribbean Islands is whether the initial inhabitants of the Bahama archipelago originated in Cuba, Hispaniola or both (Keegan \& Hofman 2017). Chronology provides no answers, as the earliest-known sites (c. AD 700-800) are located in both southern and central locations. While connections between the Turks and Caicos Islands and Hispaniola have been investigated intensively, those between the central Bahamas and Cuba have received far less attention (e.g. Sears \& Sullivan 1978; Granberry 1991; Keegan 1992, 1997; Berman \& Gnivecki 1995; Berman et al. 2013). Here we investigate possible early connections with Cuba, conducting archaeological reconnaissance of the closest Bahamian cays, namely Guinchos Cay and Cay Lobos-located only $30 \mathrm{~km}$ from the Islas del Rey (Figure 1).

Archaeological sites recorded in this adjacent Cuban archipelago range in date from 2754-2478 cal BC to European contact in 1492 (Cooper 2007). Thus, the Islas del Rey were occupied millennia before The Bahamas. Although crossing the Old Bahama Channel was within maritime abilities at that time, the main constraint would be finding these tiny, low-lying cays, which are not visible from Cuba. No archaeological evidence was found during survey of Guinchos Cay and Cay Lobos, nor during previous survey of Northwest Cay on Hogsty Reef. While positive finds would have provided important evidence of movement between the islands, the absence of evidence does not mean that these islands were never visited.

\section{Methods}

Based on prior research conducted throughout the Bahama archipelago (Keegan 1992), the methods included walkover surveys and shovel testing. All shovel tests were $0.5 \mathrm{~m}$ in diameter, dug down to sterile sand, with the matrix sieved through $6 \mathrm{~mm}$ mesh. Walkovers

\footnotetext{
1 Florida Museum of Natural History, P.O. Box 117800, University of Florida, Gainesville, FL 32611, USA

2 Turks \& Caicos National Museum, Front Street, Box 188, Grand Turk, Turks \& Caicos Islands

* Author for correspondence (Email: keegan@fmnh.ufl.edu)
}

(C) Antiquity Publications Ltd, 2018 ANTIQUITY 92 364, e10 (2018): 1-6 


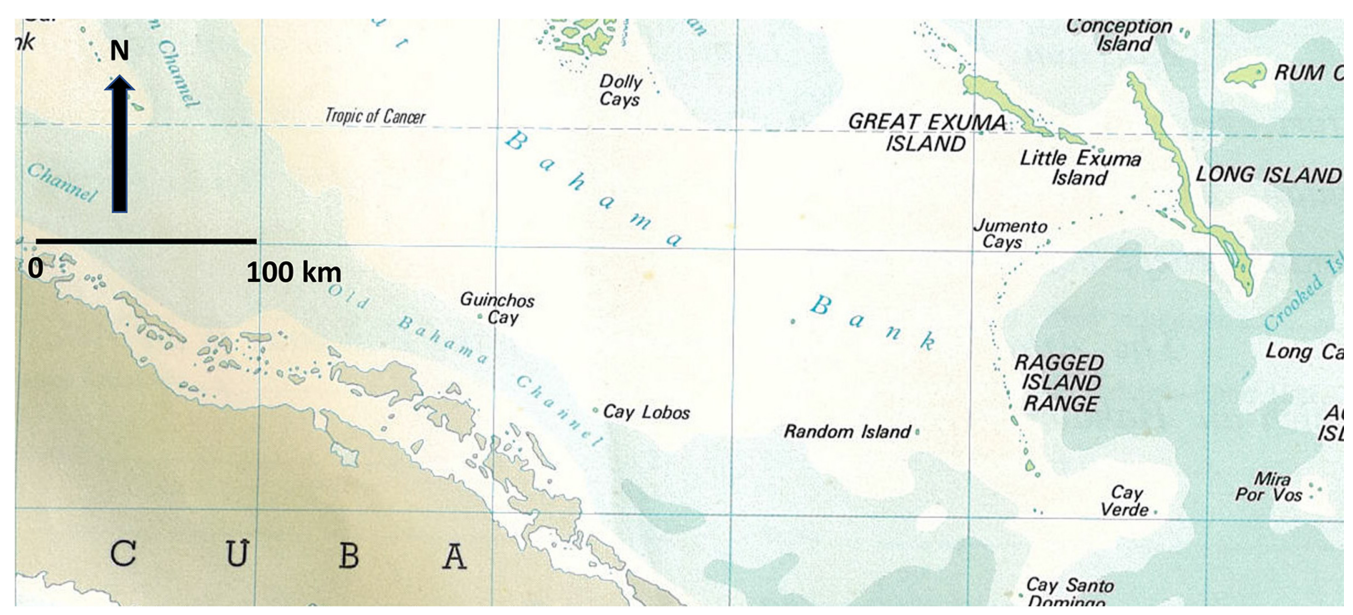

Figure 1. Location of Guinchos Cay and Cay Lobos (figure by William Keegan).

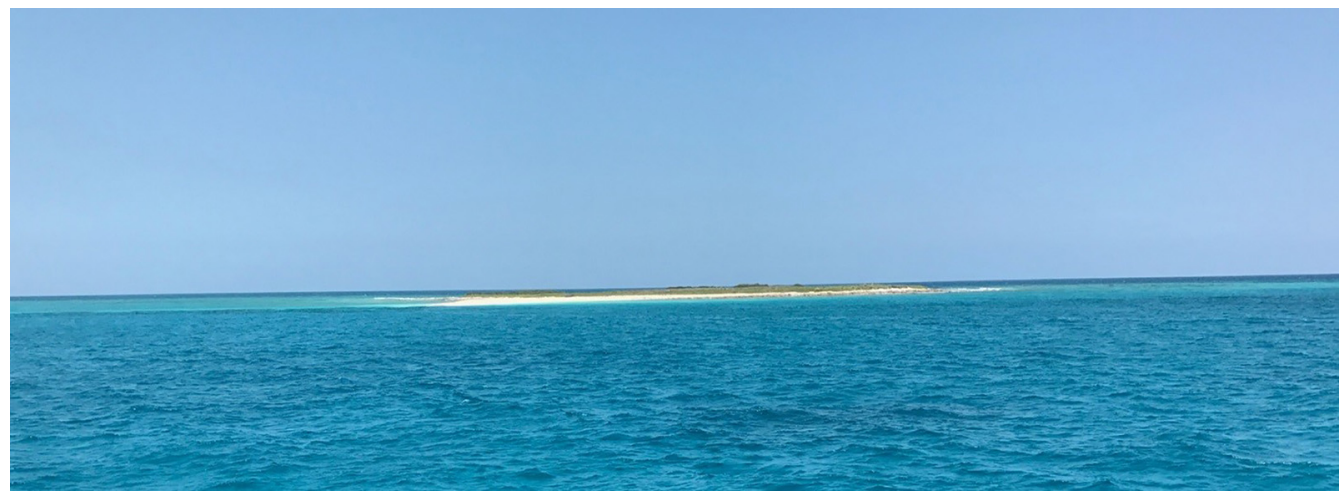

Figure 2. View of Guinchos Cay (photograph by William Keegan).

are successful because soil accumulation is slow and natural (e.g. crab burrows). Cultural disturbances expose anthropogenic evidence, and shoreline erosion (e.g. wave action) exposes stratigraphic profiles and artefacts. The most obvious indicators of human activity are the shells of consumed molluscs (e.g. Nerita spp., Codakia orbicularis, Cittarium pica, queen conch (Lobatus gigas), Tellina spp., chiton plates), fire-cracked rock, burnt conch shell and shell tools, coral tools, animal bones and anthropogenic soils. A similar survey of three small islets in the Jumentos Cays (Figure 1) identified six pre-Columbian activity areas, comprising small campsites, procurement areas or waystations used during travel to and from Cuba. Contact was confirmed by the presence of Cuban pottery sherds associated with Bahamian pottery (Keegan \& de Bry 2015). 


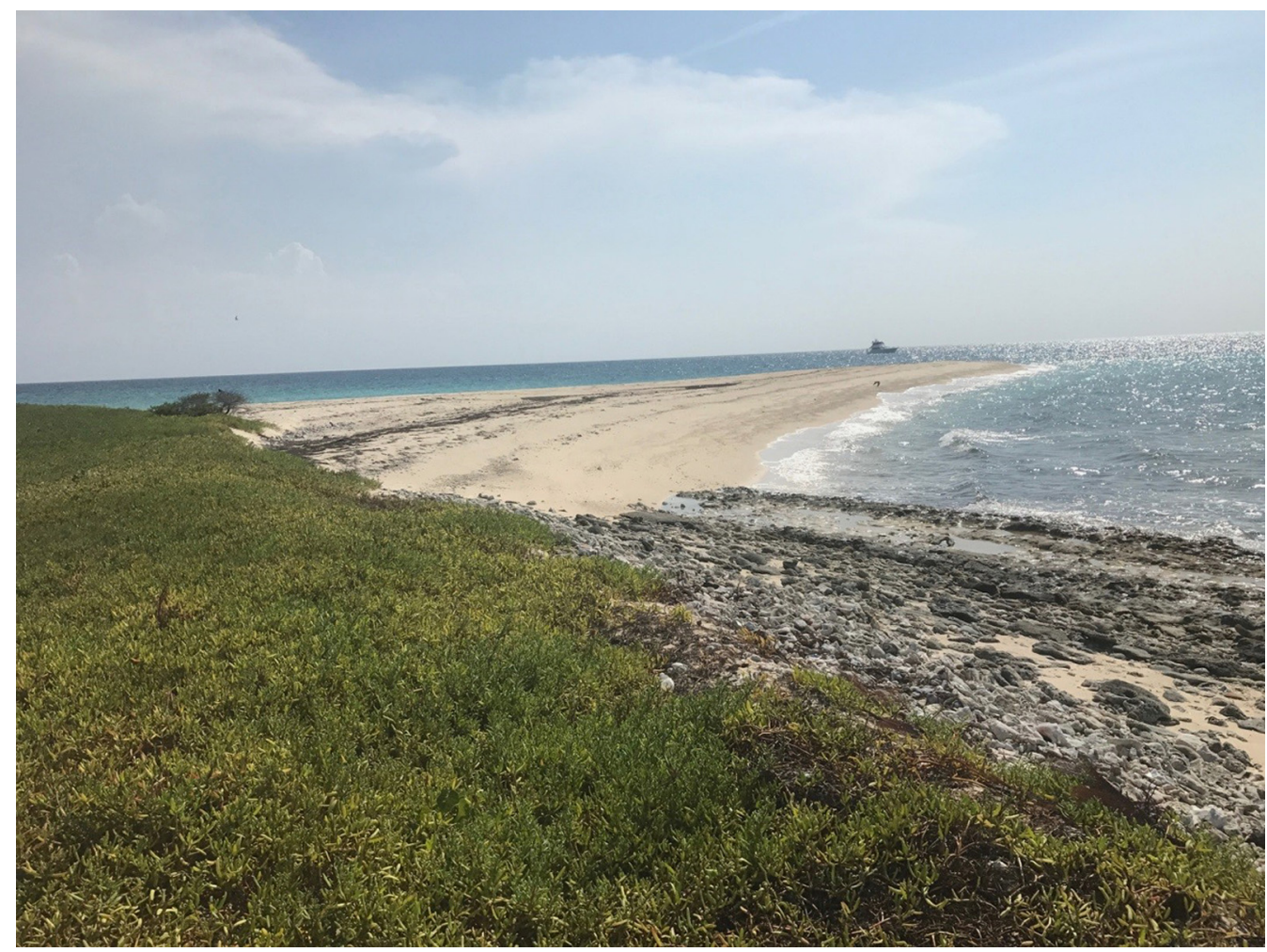

Figure 3. View of the sand spit on Guinchos Cay (photograph by William Keegan).

\section{Guinchos Cay}

Guinchos Cay is essentially a very small, circular low sand ridge, with a sand spit at the north-western corner. The cay is no more than $2 \mathrm{~m}$ asl (Figures 2-3). We performed a perimeter walkover of the beach-shoreline interface; based on previous surveys, we expected to find archaeological evidence close to the shore. To avoid disrupting nesting birds, the island was not crossed. Furthermore, dense vegetation covered most of the ground surface. The walkover revealed no prehistoric evidence. Three $0.5 \mathrm{~m}^{2}$ shovel test-pits were dug, running east at $10 \mathrm{~m}$ intervals on the rise above the beach near the sand spit. The topsoil comprised $0.2 \mathrm{~m}$-thick brown sandy loam, below which was lightly coloured natural beach sand. The soil contained small quantities of water-worn shell, coral rubble and sea turtle bones (in shovel test-pit 2). No anthropogenic evidence was found in the subsurface deposit.

\section{Cay Lobos}

Cay Lobos has a maximum elevation of approximately $3 \mathrm{~m}$ asl. The windward shore has a sharp $1 \mathrm{~m}$ rise from the beach to land, and there is a sand spit to the west. The cay has an abandoned lighthouse and outbuildings, erected in 1869 (Figure 4). Our survey covered the

(C) Antiquity Publications Ltd, 2018 


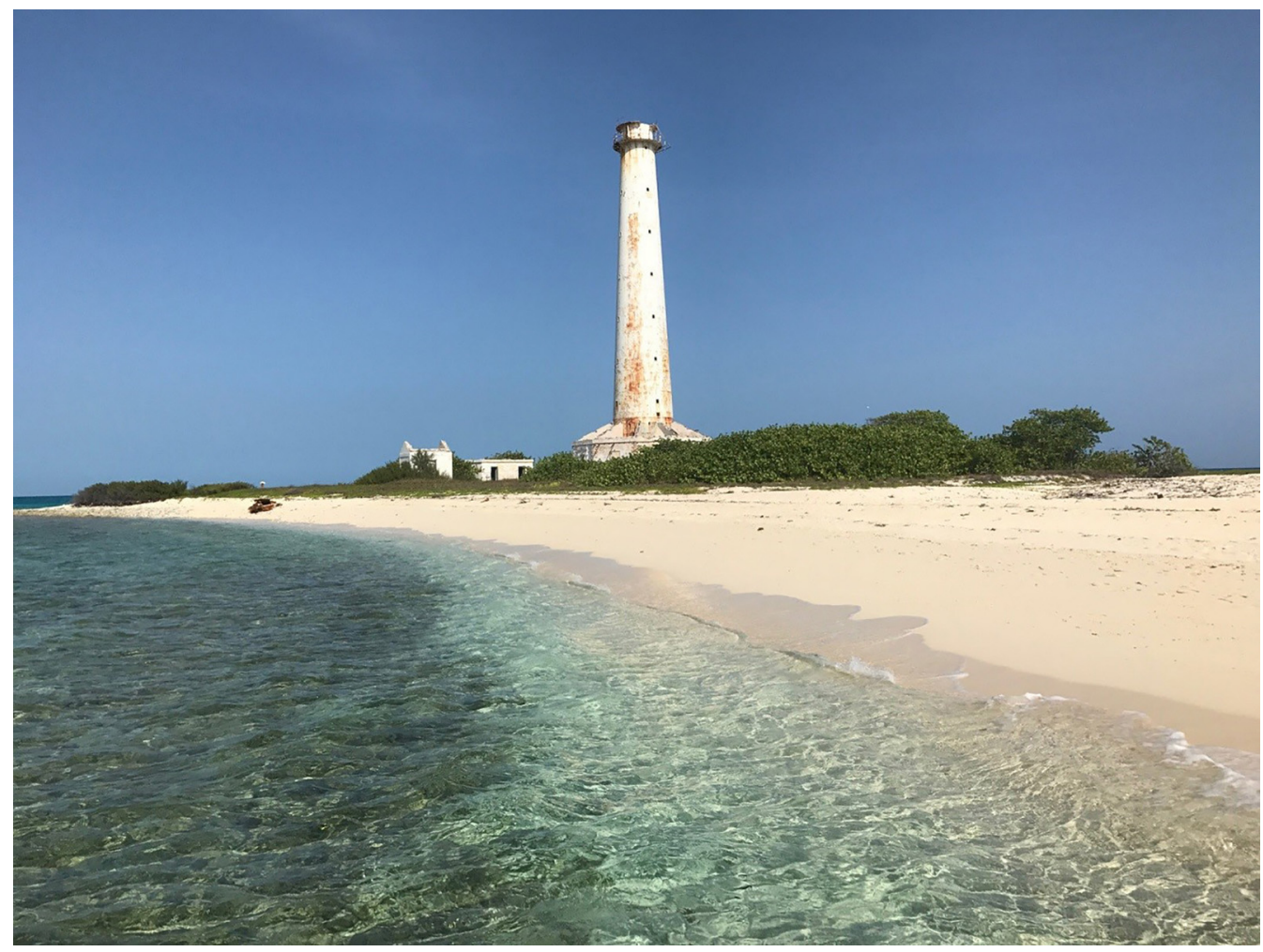

Figure 4. Lighthouse and sand spit on Cay Lobos (photograph by William Keegan).

entire cay and its surface. We found no prehistoric evidence, although most of the cay was disturbed by the construction of the nineteenth-century buildings. A contemporaneous foundation at the base of the main dune may have held fresh rainwater (Figure 5). Seven shovel tests were dug at regular intervals around the cay on the rise above the shore. In all of the shovel tests (except shovel test 3, next to a historic kitchen building), the brown sandyloam topsoil changed to lighter beach sand at about $0.4 \mathrm{~m}$ deep. Fish bones, mollusc shells and coral rubble were recovered from each of the shovel tests. No prehistoric artefacts were observed.

\section{Conclusions}

Is the absence of evidence, evidence of absence? Guinchos Cay, Cay Lobos and Hogsty Reef offer low profiles susceptible to storm surges, and have been eroded by wind and wave action over the centuries; any ancient human traces were probably very ephemeral. If these cays were used repeatedly as fishing camps or waystations, then accumulations of mollusc shells and fire-cracked rock would have been apparent. While we found no evidence that these cays were visited by the native inhabitants of the Bahama Islands, we cannot dismiss the

(C) Antiquity Publications Ltd, 2018 


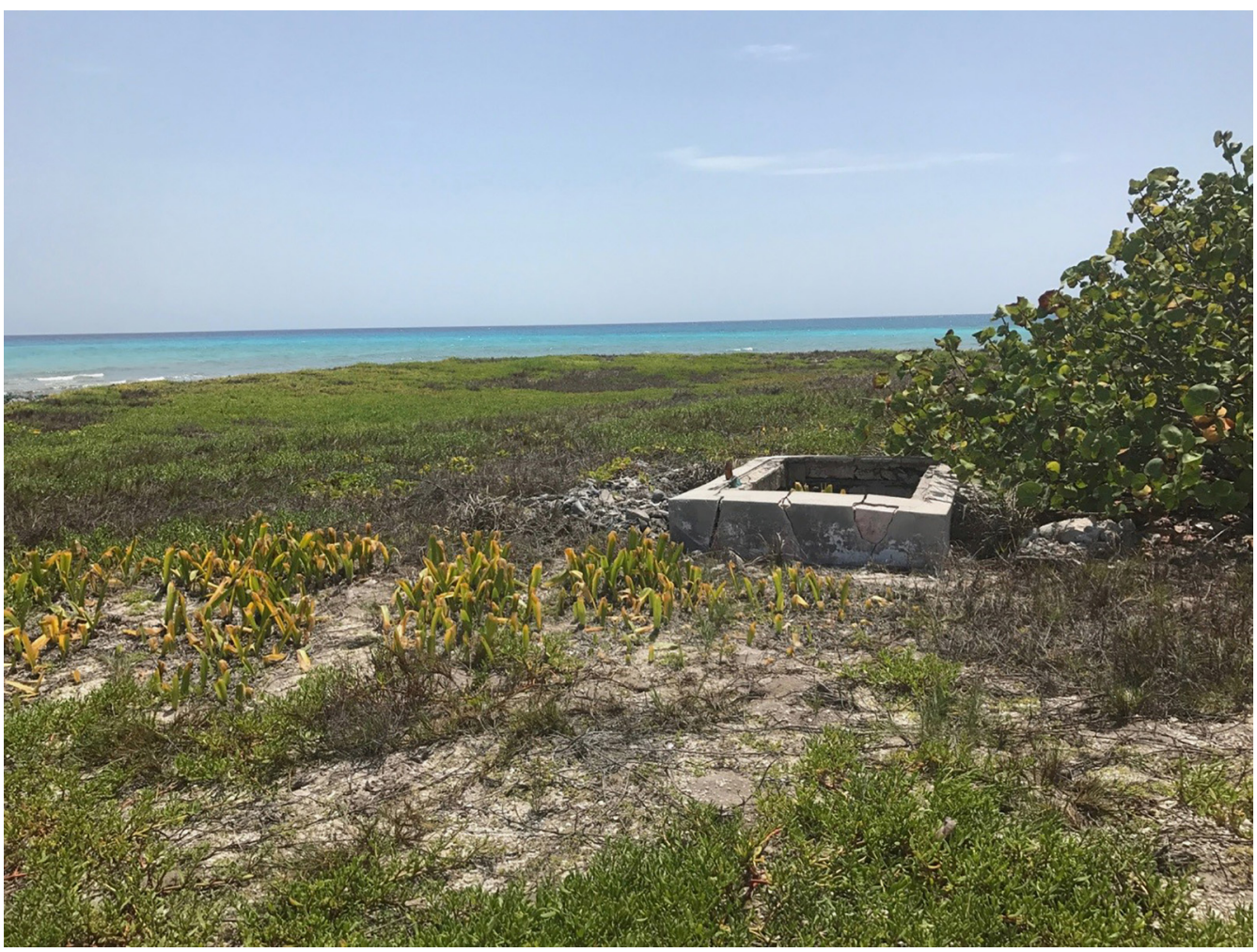

Figure 5. Structure foundation on the main dune on Cay Lobos (photograph by William Keegan).

possibility entirely. For now, we conclude that they did not play a central role in the colonisation of The Bahamas.

\section{Acknowledgements}

This research was conducted under the auspices of the Antiquities, Monuments, and Museum Corporation. We are especially grateful to Tim Nielsen, Jimmy Nielsen and Theo Nielsen for assistance in the field.

\section{References}

Berman, M.J. \& P.L. Gnivecki. 1995. The colonization of the Bahama archipelago: a reappraisal. World Archaeology 26: 421-41. https://doi.org/ 10.1080/00438243.1995.9980285

Berman, M.J., P.L. Gnivecki \& M.P. Pateman. 2013. The Bahama archipelago, in W.F. Keegan, C.L. Hofman \& R. Rodríguez Ramos (ed.) The Oxford handbook of Caribbean archaeology: 264-80. New York: Oxford University Press. https://doi.org/10.1093/oxfordhb/ 9780195392302.013 .0085

Cooper, J. 2007. Island interaction in the prehistoric Caribbean: an archaeological case study from northern Cuba.

Unpublished PhD dissertation, University College London.

Granberry, J. 1991. Lucayan toponyms. Journal of the Bahamas Historical Society 13: 3-12.

KeEgan, W.F. 1992. The people who discovered Columbus. Gainesville: University Press of Florida. 
- 1997. Bahamian archaeology: life in The Bahamas and Turks and Caicos before Columbus. Nassau: Media Publishing.

Keegan, W.F. \& J. De Bry. 2015. Archaeological reconnaissance of the Jumentos Cays, in G.T. Maria \& M.A.G. Arévalo (ed.) Proceedings of the XX Congress for Caribbean Archaeology: 187-98. Santo Domingo: Museo del Hombre Dominicano.
Keegan, W.F. \& C.L. Hofman. 2017. The Caribbean before Columbus. Oxford: Oxford University Press.

https://doi.org/10.1093/acprof:oso/ 9780190605247.001 .0001

Sears, W.H. \& S.D. Sullivan. 1978. Bahamas prehistory. American Antiquity 43: 3-25. https://doi.org/10.2307/279627 